\title{
BOVEN DIGOEL DALAM PANGGUNG SEJARAH INDONESIA: DARI PERGERAKAN NASIONAL HINGGA OTONOMI KHUSUS PAPUA
}

\author{
Susanto T. Handoko \\ Program Studi Pendidikan Sejarah FKIP Universitas Cendrawasih Jayapura \\ Alamat korespondensi: susantoth15@gmail.com \\ Diterima/Received: 12 Juli 2016; Disetujui/ Accepted: 1 Agustus 2016
}

\begin{abstract}
This study focuses on the role Boven Digoel for the Indonesian nation in the struggle for independence. The research method is a method of history to the stage of research, searches historical sources, source criticism, interpretation, and writing of history. Boven Digoel selected as a place of exile of the movement because of factors: the more intense the radical movement (communists) in Indonesia period 1925-1927 which manifests itself in a variety of labor strikes and revolts; Holland is a minor colonial power compared with the Spanish, Portuguese, French and English - that is to say, only the Dutch East Indies (Indonesia) which has a strategic significance for the survival of colonialism; Boven Digoel very far away from the center of government in Batavia covered by dense woods, filled with swamps and deserted-silent with various wild animals, ferociously malaria mosquitoes, and the original is still cannibals; Boven Digoel as the 'Land of Hope' or the future of the movement who did not return origin region. With discarded in Boven Digoel of the movement 'disconnected' at all with the people, so that they can not spread the ideas and the ideas of nationalism. Boven Digoel instrumental in the Stage History of Modern Indonesia, in particular, the national movement. Now in the Era of Reform and Special Autonomy for Papua, the existence of historical sites in Boven Digoel must be managed properly to the benefit of education and tourism development.
\end{abstract}

Keywords: Boven Digoel, National Movement, Papua Special Autonomy

\begin{abstract}
Abstrak
Kajian ini fokus pada peranan Boven Digoel bagi bangsa Indonesia dalam perjuangan mencapai kemerdekaan. Metode penelitian adalah metode sejarah dengan tahap penelitian: penelusuran sumber sejarah, kritik sumber, interpretasi, dan penulisan sejarah. Boven Digoel dipilih sebagai tempat pengasingan kaum pergerakan karena faktor: makin intensifnya gerakan radikal (komunis) di Indonesia periode 1925-1927 yang termanifestasi dalam berbagai pemogokan buruh dan pemberontakan; Negeri Belanda merupakan kekuatan kolonial yang minor dibandingkan dengan Spanyol, Portugis, Perancis, dan Inggris - artinya, hanya wilayah Hindia Belanda (Indonesia) yang memiliki arti strategis bagi keberlangsungan kolonialisme. Jarak Boven Digoel sangat jauh dari pusat pemerintahan di Batavia yang diselimuti oleh hutan belukar lebat, penuh dengan rawa-rawa dan sunyisenyap dengan beraneka ragam binatang buas, ganasnya nyamuk malaria, dan suku asli yang masih kanibal; Boven Digoel sebagai 'Tanah Harapan' atau masa depan bagi kaum pergerakan yang tidak kembali ke daerah asalnya. Dengan di-Digoel-kan kaum pergerakan 'terputus' sama sekali dengan rakyatnya, sehingga mereka tidak bisa menyebarkan gagasan dan ide-ide kebangsaan atau nasionalisme. Boven Digoel berperan penting dalam Panggung Sejarah Indonesia Moderen, khususnya masa pergerakan nasional. Kini di Era Reformasi dan Otonomi Khusus Papua, eksistensi situs sejarah di Boven Digoel harus segera dikelola dengan baik untuk kepentingan pembangunan pendidikan dan pariwisata.
\end{abstract}

Keywords: Boven Digoel, pergerakan nasional, otonomi khusus Papua. 


\section{PENDAHULUAN}

Dalam lintasan Sejarah Indonesia Modern ada suatu tempat yang telah terlupakan dalam memori kolektif bangsa Indonesia yaitu Boven Digoel. Daerah Boven Digoel letaknya di hulu Sungai Digoel, Papua bagian Selatan. Wilayah ini pada awalnya diselimuti oleh hutan belukar lebat, penuh dengan rawa-rawa dan sunyisenyap dengan beraneka ragam binatang buas. Oleh karena itu, Pemerintah Kolonial Belanda merasa cocok untuk mendirikan kamp konsentrasi (sering disebut sebagai tempat pembuangan/pengasingan) bagi para tahanan politik di wilayah ini. Selanjutnya, Boven Digoel dibangun sebagai suatu tempat pembuangan dengan Surat Keputusan Pemerintah Hindia Belanda tanggal 10 Desember 1926 (Mangunadikusumo, 1977: 73). Pada waktu itu Pemerintah Kolonial Hindia Belanda dipimpin oleh Gubernur Jenderal A.C.D. de Graeff.

Wilayah Boven Digoel masa kolonial telah dihuni oleh penduduk asli atau lokal dengan cara hidupnya yang masih sangat sederhana atau tradisional dan dapat dikatakan belum mengenal peradaban. Sistem pengayauan dan kanibalisme masih mendominasi tatanan kehidupan penduduk setempat. Penduduk asli atau lokal tersebut terdiri dari beberapa suku antara lain: suku Muyu, suku Mandobo, suku Auyu Darat, suku Auyu Kali, dan suku Kombay-Koroway (suku Auyu Gunung) yang hidup secara terpisah (Handoko dkk., 2008: 2 ).

Kurun waktu 1914-1922 terutama di daerah pesisir Sungai Digoel telah terjadi praktik-praktik perburuan liar terhadap burung Cenderawasih yang dilakukan oleh orang Cina atau sering disebut sebagai tukang-tukang pasang (Prisma No. 7, 1988: 48). Oleh karena itu, Pemerintah Kolonial Hindia Belanda membuka pos keamanan Asiki. Pos tersebut dibangun untuk menjaga dan mengatasi sukusuku pengayau dan kanibalis serta pengawasan terhadap praktik-praktik perburuan liar oleh orang-orang tukang pasang. Akan tetapi, pos tersebut tidak bertahan lama, karena kondisi alam yang sangat ganas.

Periode 1927 hingga 1942 para interniran diasingkan di tempat yang sama, yaitu di Kamp Konsentrasi Boven Digoel (Shiraishi, 2001: 1-2). Oleh karena itu, sejak akhir tahun 1926, pascapemberontakan Pemberontakan Komunis Indonesia (PKI) di Banten, dan pemberontakan PKI di Sumatera Barat 1927, hingga 1940-an, ribuan aktivis pergerakan telah dikirim ke Kamp Konsentrasi di Boven Digoel. Di antara mereka adalah para aktivis dan tokoh dari PKI, Partai Republik Indonesia (PARI), Partai Nasional Indonesia (PNI), Partai Indonesia (PARTINDO), Perhimpunan Muslim Indonesia (PERMI), Partai Sarikat Islam Indonesia (PSII), dan beberapa lainnya.

Selain tokoh-tokoh partai politik tingkat nasional, pada perkembangan berikutnya khususnya setelah Indonesia merdeka, dan Tanah Papua masih berada di bawah kekuasaan kolonial Belanda, Kamp Konsentrasi Boven Digoel tetap difungsikan sebagai tempat buangan bagi elite-elite Papua yang menentang kekuasaan penjajah Belanda. Di antara mereka adalah para aktivis dan tokoh dari berbagai organisasi pergerakan pendukung Proklamasi Indonesia yang tumbuh dan berkembang di Tanah Papua antara 1946 hingga 1963.

Di Era Reformasi Indonesia (Otonomi Daerah dan Otonomi Khusus Papua), Boven Digoel terbentuk berdasar Undang-Undang Nomor 26 Tahun 2002 sebagai kabupaten baru. Bersamaan dengan undang-undang tersebut juga dibentuk Kabupaten Mappi dan Kabupaten Asmat, ketiganya merupakan pemekaran dari Kabupaten Merauke (Kompas, 29 Mei 2012). Sejak terbentuknya Kabupaten Boven Digoel secara definitif membuat geliat pembangunan di berbagai sektor kehidupan berkembang secara signifikan, khususnya infrastruktur jalan yang menghubungkan Kota Merauke dengan Tanah Merah, sarana dan prasarana publik dan lainnya.

Kota Tanah Merah (kini ibukota Kabupaten Boven Digoel) dahulu merupakan 
pusat kota Onderaafdeling Boven Digoel, yang oleh orang Belanda disebut sebagai Deportatie Kamp Boven Digoel. Karena di Tanah Merah dijadikan kamp konsentrasi tokoh-tokoh pejuang pergerakan Indonesia oleh Pemerintah Kolonial Hindia Belanda. Daerah Boven Digoel terletak di hulu Sungai Digoel yang $\pm 450 \mathrm{~km}$ dari pantai Selatan Papua. Onderaafdeling Boven Digoel ketika itu dimasukkan ke dalam wilayah Gubernuran Maluku. Jarak dari muara sungai ke Tanah Merah sama dengan jarak dari Batavia (Jakarta) ke Semarang atau dari Amsterdam ke Paris dan terletak di tengah hutan belantara yang tidak bersahabat (Shiraishi, 2001: 17).

Boven Digoel dengan pusat kotanya di Tanah Merah mulai dikenal sejak diadakan penelitian geologi pada 1900 dan 1913, dan hasil penelitian tersebut menunjukkan bahwa wilayah yang meliputi 10 ribu hektar itu dinyatakan cocok untuk pertanian, karena iklimnya sehat dan cukup banyak persediaan air serta curah hujannya normal (Prisma No. 7, 1988: 15).

Kajian ini mengambil periode dari awal terbentuknya Onderaafdeling Boven Digoel hingga terbentuknya dan perkembangan Kabupaten Boven Digoel di era Reformasi (Otonomi Daerah dan Otonomi Khusus Papua). Onderaafdeling Boven Digoel dibentuk dengan Surat Keputusan Pemerintah Kolonial Hindia Belanda tanggal 10 Desember 1926 berkenaan dengan rencana pembuangan dan pengasingan kaum pergerakan bangsa Indonesia yang dianggap berbahaya. Sebelum terbentuknya Kabupaten Boven Digoel hingga 2000, Tanah Merah sebagai pusat ibukota Kecamatan Mandobo, yang merupakan salah satu kecamatan dalam wilayah administratif Kabupaten Merauke. Akan tetapi, dengan berlakunya Undang-Undang Republik Indonesia Nomor 26 Tahun 2003 tentang program pemekaran wilayah kabupaten, dan Boven Digoel merupakan salah satu wilayah yang dimekarkan, maka kini Tanah Merah menjadi ibukota atau pusat pemerintahan Kabupaten Boven Digoel.
Kabupaten Boven Digoel yang dimekarkan pada 12 April 2003 itu memiliki luas wilayah $27.108 \mathrm{~km}^{2}$ dengan jumlah penduduk sebanyak 39.549 jiwa yang terdiri dari laki-laki 20.218 jiwa dan perempuan 19.331 jiwa. Jumlah penduduk tersebut menyebar di 6 distrik dan 88 kampung (Suara Perempuan Papua, 7-12 Agustus 2006: 13). Sebagai ibukota kabupaten baru, kini di Tanah Merah penduduknya sudah heterogen. Di luar tiga suku besar Papua, yaitu Mandobo, Muyu, dan Auyu, terselip suku-suku asli Papua yang datang dari luar Digoel dan pendatang dari pulau lain (Yuniarti dan Verdiansyah, 2007: 118).

Kajian ini hendak melihat kedudukan wilayah Boven Digoel khususnya peranan Kamp Konsentrasi Boven Digoel bagi bangsa Indonesia terutama dalam usaha perjuangan mencapai kemerdekaan. Oleh karena itu, permasalahan dalam penelitian ini dapat dirumuskan sebagai berikut: (1) Apa yang melatarbelakangi Pemerintah Kolonial Hindia Belanda menjadikan Boven Digoel sebagai salah satu Kamp Konsentrasi Politik di Nusantara?; (2) Bagaimana eksistensi wilayah Boven Digoel dalam Lintasan Sejarah Indonesia?; (3) Bagaimana eksistensi dan prospek situs-situs sejarah di Boven Digoel di Era Otonomi Khusus?

Bertolak dari uraian di atas, maka kajian ini bertujuan mendeskripsikan keberadaan atau peranan yang dimainkan oleh Boven Digoel dalam lintasan Sejarah Indonesia kaitannya dengan Pergerakan Nasional Indonesia dan pembangunan bangsa saat ini, khususnya pembangunan di Boven Digoel dan Papua. Oleh karena keberadaan situs sejarah di Boven Digoel menandakan ada keterkaitan antara Boven Digoel dengan masa kolonial, maka situs sejarah di Boven Digoel saat ini tentunya memiliki nilai historis dan dapat dimanfaatkan bagi pembangunan di Boven Digoel khususnya bidang pendidikan sejarah dan pariwisata. 


\section{METODE}

Artikel ini didasarkan pada penelitian Boven Digoel Dalam Sejarah Indonesia: Inventarisasi dan Dokumentasi Eks Penjaran Boven Digoel (Handoko dkk, 2008) dan Frans Kaisiepo Pahlawan Nasional Asal Papua (Handoko, 2011). Dalam dua penelitian tersebut digunakan metode sejarah untuk proses pengumpulan data hingga pelaporan hasilnya. Dalam metode sejarah dikenal tahap-tahap penelitian, yaitu: penelusuran sumber sejarah (historiografi), kritik sumber (verifikasi), interpretasi dan eksplanasi, dan penulisan sejarah (historiografi) (Garraghan, 1957: 33; Gottcshalk, 1986: 13; Renier, 1997: 113-118; Suhartono, 2010: 29-56).

Heuristik merupakan langkah awal dari penelitian ini yang berisikan kegiatan penelusuran sumber sejarah. Pengumpulan data dilakukan dengan metode penggunaan bahan dokumen. Penelitian dokumentasi dilakukan di sejumlah perpustakaan di Jayapura, Boven Digoel, dan Biak. Sumber sejarah yang diteliti meliputi: majalah sezaman, manuskrip, catatan pribadi, piagam, foto, dan akta. Peneliti juga melakukan studi lapangan untuk menemukan berbagai monumen peninggalan dan melakukan wawancara dengan tokoh pejuang atau ahli waris tokoh serta anggota masyarakat lain yang mengetahui berbagai kejadian pada masa itu.

Konsekuensi logis di dalam metode sejarah, setelah penulis berhasil mengumpulkan data yang diperlukan adalah melakukan kritik sumber, baik secara eksternal maupun internal. Kritik eksternal digunakan untuk menilai otentisitas sumber, sedangkan kritik internal digunakan untuk menilai kredibilitas sumber. Sumber dokumen yang dikeluarkan pemerintah seperti: piagam dan akta pada umumnya dapat dipercaya; dan sumber lain seperti majalah sejaman, manuskrip, catatan pribadi tokoh perlu dicermati dengan seksama. Pada tahap ini penulis melakukan proses verifikasi bahan dokumen (kolasi), yaitu membandingkan antara beberapa dokumen, sehingga terlihat adanya kesesuaian maupun kontradiksi antar fakta. Dalam kondisi ketika terdapat fakta yang kontradiktif, maka dilakukan seleksi atas derajat keterpercayaan sumber, dengan memilih sumber primer yang dapat dijadikan sumber data yang representatif sehingga diperoleh fakta sejarah yang dapat dipertanggungjawabkan orisinalitasnya.

Fakta sejarah yang dihasilkan dari proses kritik sumber sejarah bersifat tunggal. Untuk mengaitkan antarsumber dilakukan proses penafsiran atau interpretasi dan penjelasan hubungan antarfakta (ekplanasi). Interpretasi meliputi interpretasi verbal, interpretasi teknis, interpretasi logis, interpretasi psikologis, dan interpretasi faktual. Penulisan sebagai tahap akhir dari penelitian memperhatikan aspek kronologis, dan penyajiannya berdasar tematema penting dari setiap perkembangan objek penelitian. Aspek-aspek nonindividu menjadi narasi penting dalam kajian ini dalam bingkai waktu, sehingga digunakan analisis prosesual dan struktural (Kartodirdjo, 1992; Kuntowijoyo, 2003; Wasino, 2016: 64).

\section{KAMP KONSENTRASI BOVEN DIGOEL MASA PERGERAKAN NASIONAL}

\section{Pendirian Kamp Konsentrasi Boven Digoel}

Setelah pemberontakan komunis di Banten 1926 dan di Sumatera Barat 1927, rezim Kolonial Hindia Belanda membangun sebuah Kamp Konsentrasi di Boven Digoel Papua. Seperti dijelaskan oleh Pemerintah Kolonial Hindia Belanda, pembuangan bukanlah sanksi yang dijatuhkan melalui proses hukum (penal sanction), melainkan tindakan administratif, ditetapkan oleh kewenangan istimewa gubernur jenderal (exorbitant rechten), yang bisa menentukan para interni hidup di tempat tertentu (Shiraishi, 2001: 1).

Sebetulnya pengasingan (dalam hal ini pembuangan keluar) sudah lazim dikenal dan telah berlangsung lama di negara jajahan Hindia Belanda. Di abad ke-20 misalnya, Surontiko Samin, orang Jawa Tengah dibuang ke Sumatera Barat pada 1907. Pada 1920 Cipto 
Mangunkusumo dikenai larangan menetap di wilayah penduduk berbahasa Jawa di Jawa Tengah dan Jawa Timur, dan selanjutnya dibuang ke Banda Neira 1927. Tokoh lain seperti Semaun, Tan Malaka, Darsono, Haji Misbach, Ali Archam, dan masih banyak lainnya, ditolak menetap di Hindia Belanda atau diwajibkan menetap di beberapa tempat berbeda di bagian timur kepulauan antara 1919 hingga 1926. (Shiraishi, 2001: 1-2). Baru pada 1927 hingga 1943 para interniran diasingkan di tempat yang sama yaitu Kamp Konsentrasi Boven Digoel.

Pendirian kamp konsentrasi massal diputuskan pada sebuah pertemuan luar biasa Dewan Hindia Belanda (Raad van Nederlandsch-Indie) yang diadakan pada 18 November 1926, kurang dari satu minggu sejak pemberontakan komunis yang berawal di Jawa Barat pada 12 November (Shiraishi, 2001: 3-4). Pada saat itu pertanyaan yang dikemukakan oleh Gubernur Jenderal de Graeff adalah: "Bilakah sejumlah tindakan harus diambil untuk memerangi meningkatnya gerakan komunis yang berlangsung satu minggu terakhir dan untuk mencegah (pengulangan mereka) di masa datang sebisa mungkin. Jika ya, tindakantindakan seperti apa?"

Dewan Hindia Belanda (Raad van Nederlandsch-Indie) akhirnya mendukung usulan de Graeff dan memutuskan bahwa pengasingan harus dimulai pada mereka yang ditangkap di Jawa Barat. Sementara itu, pengasingan bagi mereka yang ditahan di berbagai tempat akan mengikuti secepatnya setelah kantor jaksa umum, hoofdparket, menerima informasi yang diperlukan bagi tindakan tersebut. Selanjutnya, diputuskan pula bahwa prosedur dan formalitas yang harus dipenuhi bagi pengasingan direvisi dan disederhanakan untuk pemberlakuannya. Alasaan-alasan yang diberikan dalam rancangan keputusan pengasingan harus jelas dan dibatasi, intinya bahwa orang yang bakal diasingkan adalah anggota PKI, partai yang bermaksud menggulingkan dan membentuk pemerintah baru dengan jalan radikal.
Mengenai ide munculnya Boven Digoel dipilih sebagai tempat pembuangan massal dapat diuraikan disini. Paling tidak ada dua hal yang perlu diperhatikan. Pertama, idenya sudah ada sebelum pemberontakan supaya ada tempat khusus didirikan sebagai tempat buangan. Karena orang-orang komunis waktu itu, mereka kerjanya keluar dan masuk penjara. Jadi ide itu sudah ada sejak tahun 1925, dan ide itu dijalankan begitu pemberontakan terjadi. Kedua, Belanda adalah kekuatan kolonial yang minor. Bukan yang nomor satu, tetapi ketiga setelah Inggris dan Perancis. Koloni satusatunya yang mereka punya dan berarti adalah Hindia Belanda. Lain dari Inggris, punya banyak koloni, jadi punya banyak pilihan untuk membuang/mengasingkan tokoh-tokoh pergerakan atau pemberontakan. Menurut pertimbangan pemerintah kolonial lebih baik mendirikan satu tempat di Hindia Belanda yang mampu menampung ribuan kaum buangan. $\mathrm{Hal}$ lain bisa ditambahkan, bahwa Gubernur Jenderal de Graeff waktu itu masih percaya dengan kemungkinan untuk membangun Papua sebagai wilayah yang baru. Karena waktu itu Papua memang belum dibangun sama sekali. Jadi de Graeff percaya akan ada kesempatan untuk mendirikan suatu wilayah yang baru, yang makmur dan tenteram untuk orang-orang komunis, dan sekaligus juga akan menjadi salah satu wilayah yang baik untuk Hindia Belanda.

Sebetulnya ada begitu banyak pulau lain di Hindia Belanda, dan pada waktu itu begitu banyak daerah yang belum dibuka untuk wilayah baru. Mengapa justru Digoel yang dipilih. Yang penting diperhatikan adalah tempat pembuangan harus terisolasi $100 \%$. Dan orang yang diutus mencari tempat pembuangan yang baru itu adalah Gubernur Propinsi Maluku. Karena Papua juga termasuk bagian Propinsi Maluku, maka dia mengusulkan Boven Digoel yang paling baik. Atas usulan dari Gubernur Maluku itu Dewan Hindia lalu menentukan Boven Digoel sebagai tempat pembuangan. Barangkali ada tempat-tempat yang lain. Akan tetapi, menurut Gubernur Maluku, Boven Digoel itu ideal sebagai tempat buangan karena $100 \%$ terisolasi. Jaraknya dari 
muara Sungai Digoel itu $455 \mathrm{~km}$ ke hulu, ke pedalaman. Itu sama dengan jarak Jakarta ke Semarang, atau dari Amsterdam ke Paris. Kondisi saat itu semuanya hutan lebat, rawarawa yang banyak nyamuk malaria, dan di sungainya banyak buaya. Terlebih saat itu banyak penduduk aslinya yang masih head hunter, atau masih kanibal, masih suka makan orang.

\section{Kedatangan Rombongan Interni Pertama}

Pada 10 Desember 1926, wilayah Sungai Digoel dipisahkan dari subdivisi (Onderafdeeling) dari Papua bagian selatan melalui dekrit pemerintah dan dijadikan sebuah pemerintahan subdivisi Boven Digoel dengan Tanah Merah sebagai pusat pemerintahannya (Mededeelingen der Regeering omtrent Enkele Onderwerpen van Algemeen Belang, Mei 1928). Tidak lama setelah itu, Kapten L. Th. Becking, pimpinan kesatuan yang menghancurkan pemberontakan November di Banten, dikirim ke Digoel dengan pasukannya yang kebanyakan berasal dari Ambon dan tawanan pekerja (convict worker) untuk membangun kamp tepat pada waktunya bagi kedatangan rombongan pertama para interni yang dijadwalkan tiba pada 27 Maret 1927.

Kapten Becking dengan orang-orangnya dan tawanan pekerja tiba di Tanah Merah pada Januari 1927. Selama dua bulan mereka membangun barak, gudang, rumah sakit, stasiun radio, kantor pos, dan tempat mandi besar (badvlo) di aliran sungai bagi tentara dan tawanan. Rombongan pertama interni dan keluarganya tiba Maret 1927. Ada 50 interni, termasuk seorang Cina, dan 30 keluarga. Semuanya berpakaian rapi, dengan kostum tropis berwarna-warni, bersepatu dan kaos kaki bersih, topi, koper, dan sebuah payung yang dikempit di bawah lengan (Salim, 1973: 78-84)

Penduduk Digoel terus bertambah stabil mulai saat itu. Ketika pengawas M.A. Monsju tiba, bersama dengan rombongan ketujuh interni di Tanah Merah pada 30 Oktober 1927 untuk menggantikan Kapten Becking sebagai penguasa Digoel. Pihak pemegang wewenang atau administratur mencatat bahwa penduduk kamp berjumlah sekitar 920 jiwa, terdiri dari 538 interni dan 382 anggota keluarga. Selanjutnya, pada Februari 1928, angka ini mencapai 1.139 jiwa, terdiri dari 666 interni dan 473 anggota keluarga. Ketika W.P. Hillen, anggota Dewan Hindia Belanda mengunjungi Digoel pada bulan April 1930, penghuni kamp berada di titik puncak, dengan 2.000 jiwa, termasuk 1.308 interni (Shiraishi, 2001: 10).

\section{Kamp Konsentrasi Tanah Merah}

Tanah Merah terdiri dari tiga wilayah yang berbeda yang dipisahkan oleh sungai-sungai kecil, yaitu: (1) wilayah administratif (bestuursterrein di mana para pejabat sipil tinggal; (2) wilayah militer; (3) kamp konsentrasi (pembuangan) di mana para interni ditempatkan.

\section{Wilayah Administratif}

Kantor utama administrasi kampung berada di Kampung B. Pemerintahan kampung ini dipimpin oleh Gondoyuwono, kemudian Budisucitro. Kampung ini memiliki satuan polisi sendiri yang bernama ROB (Rust en Orde Bewaarders), yang berarti Penjaga Ketertiban dan Tatanan. ROB bekerja sama dengan pemerintah lokal dan satuan polisi pemerintah lokal. Tahun-tahun pertama satuan polisi ini dipimpin oleh Suprapto dari Salatiga.

Di sebelah toko Tan Tjo berderet rumahrumah kediaman bagi pejabat-pejabat urusan pribumi, dibangun pertama kali pada 1927 untuk wedana (kepala distrik) dari Sunda, Suria Atmadja, dan asisten wedana dari Minangkabau, Bitek. Lebih jauh lagi di sepanjang jalan berbatu itu terletak kantor administrasi, di mana beberapa interni bekerja bersama dengan kepala pemerintahan lokal, dua pejabat (commiezen), sejumlah kecil juru tulis Ambon, wedana, dan asisten wedana. Kasuskasus kriminal disidangkan di bangunan ini dengan kepala administratif sebagai hakim. Kasus-kasus yang ada kebanyakan tentang 
pelanggaran-pelangggaran ringan, termasuk urusan wanita, dan kadang-kadang tindak kekerasan. Di gedung ini terdapat sebuah ruangan khusus yang tertutup, Arsip Digoel, tempat catatan para interni yang terus membengkak oleh informasi yang datang terusmenerus dari para mata-mata dan informan yang melaporkan tingkah laku interni, semuanya diklasifikasikan secara sistematis, rapi, dan tersimpan baik (Shiraishi, 2001: 22).

Di sebelah utara gedung administrasi berdiri sebuah gereja Protestan di tengah padang rumput. Di depan gereja, tepat dimana jalan berbatu berbelok ke arah timur, terdapat rumah satu-satunya dokter di Digoel berdekatan dengan rumah-rumah pejabat sipil dan perwira polisi. Lebih jauh lagi ke arah pedalaman terhampar sebuah ladang rumput, sebelumnya ada ladang buatan dari penebangan hutan yang dimaksudkan untuk menanam padi atas perintah asisten wedana dalam rangka menjadikan Digoel "memenuhi kebutuhan sendiri". Proyek penanaman padi ini gagal. Sawah-sawah buatan dibiarkan kosong selama bertahun-tahun, tetapi beberapa tahun terakhir para interni menanam sayur-sayuran dan tanaman lain di sana, yang menjadikan Digoel berswasembada sayuran (Shiraishi, 2001: 22).

\section{Wilayah Militer}

Di kamp militer terdapat barak-barak militer, kantor komandan garnisun, bangsal orang sakit, gudang amunisi, stasiun radio, kantin, penjara, dapur umum, asrama wanita, dan lapangan kecil untuk olah raga. Fasilitsafasilitas asli kamp ini dibangun secara tergesagesa pada 1927, terdiri dari kayu dan alangalang. Pada 1934, Gubernur Jenderal de Jonge memutusakan untuk mengubah kamp menjadi semi-permanen, di luar fakta bahwa ia dengan panik memotong anggaran belanja pemerintah di berbagai sektor dan tempat untuk menyesuaikan dengan krisis keuangan yang diakibatkan oleh depresi ekonomi. Meskipun keputusannya mempertahankan Digoel tak diketahui para interni, mereka bisa merasakan dari renovasi kamp militer untuk bisa memahami bahwa kamp pembuangan telah dibuat menjadi semi-permanen oleh pemerintah.

Kamp militer mula-mula hanya terdiri dari lima rumah. Namun perkembangan selanjutnya menjadi tujuh peleton infantri, setiap peleton terdiri 16 hingga 20 personel di bawah komando seorang tentara Eropa atau pribumi berpangkat sersan. Misi mereka menjaga keamanan dan tatanan di Tanah Merah, melakukan tugas penjagaan secara periodik di Tanah Tinggi, dan melakukan patroli ke seluruh wilayah Digoel. Seperti di tempat lain di Hindia Belanda, keluarga para tentara juga tinggal di kamp, di barak-barak yang terpisah. Oleh karena itu, tampak sebuah dunia kecil mereka di dalam kamp militer, terpisah dari seluruh kehidupan Digoel.

\section{Kamp Konsentrasi (Pembuangan)}

Pada mulanya para interni hidup terpisah, terkotak-kotak menurut etnis. Di ujung utara kamp, di tepi sungai, adalah Kampung Ujung Sumatera, yang penghuninya mayoritas etnis Minangkabau. Etnis Aceh dan Lampung menetap terpisah. Orang-orang dari Jawa: etnis Madura, Jawa, dan Sunda - berkumpul di pemukiman sendiri. Orang Banten, sebagian besar mereka yang turut dalam pemberontakan 1926 di Banten, membentuk sebuah kelompok terpisah. Konflik sering terjadi antara orang Jawa dan Sumatera. Orang Sumatera menganggap hal yang bodoh menyaksikan seorang pejabat interni Jawa ketika bepergian selalu diikuti seorang interni yang memayunginya. Mereka juga mengejek seni Jawa, tembang, tandak, wayang, dan ketoprak, sebagai seni feodal. Bagaimanapun, karena waktu dan semakin banyak interni generasi awal dipulangkan, perbedaan etnis menjadi kurang berperan dalam pola huni.

Para interni banyak membuat asosiasi: klub opera Orient, grup musik dan opera Liberty, teater Sunda Kebinangkitan Pasundan, grup kethoprak dan wayang orang Jawa, Langen Oedo Matojo, dan grup keroncong. Klub paling penting, yang bertahan hidup hingga hari terakhir Digoel, adalah Asosiasi Seni dan Olah Raga Digoel (Kunst en Sportvereeniging Digoel). 
Asosiasi ini didirikan pada 1928 di bawah pimpinan Winanta. Masuk dalam asosiasi ini adalah grup jazz Abdul Xarim dan Konser Digoel.

Di ujung utara jalan utama, berbatasan dengan hutan, terdapat sisa-sisa Kampung Ujung Sumatera yang lama terbengkelai tepat di tepi sungai, dan di sebelahnya, tanah makam yang terawat baik hingga hari penutupan kamp. Mereka yang meninggal di Tanah Tinggi, termasuk Marco dan Aliarcham, juga dimakamkan di sini. Sebagian besar mereka meninggal karena penyakit malaria.

Di dekat pemakaman jalan dan jika kita berbelok ke timur, maka di sepanjang wilayah ini ada sisa-sisa Kampung D, E, F, dan G, yang sebelum akhir 1930-an telah terkubur semaksemak dan kembali dikuasai alam. Pemukiman ini ditinggalkan penghuninya satu per satu sejak awal 1930-an ketika para interni mendapatkan pembebasan bertahap dan penduduk kamp pembuangan menyusut dari angka tertinggi 2.100 pada 1929 menjadi kurang dari 1.000 pada pertengahan 1930-an. Penduduk kamp pembuangan di akhir 1939 seluruhnya ada 580 orang, terdiri dari 355 pria, 66 wanita, dan 159 anak-anak (Shiraishi, 2001: 29).

\section{Empat Kategori Kehidupan Struktural di Tanah Merah}

Kehidupan di Digoel tidak mudah, tetapi kehidupan seperti apa adanya, kehidupan sosial dan keluarga dengan kebahagiaan-kebahagiaan sederhana dan kekacauan-kekacauan kecil. Digoel, dengan istana kecil Oranye Park, garnisun militer, dan pemukiman penduduk asli, tampak seperti kota kecil lain di Hindia Belanda, bahkan seperti Buitenzorg kecil. Akan tetapi, kehidupan di Digoel adalah kehidupan ganjil. Kehidupan yang "normalitas ganjil" inilah, meminjam ungkapan Rudolf Mrazek, yang bisa diidentifikasi sebagai ciri utama Digoel (Mrazek, 1994: 141).

Digoel ada;ah sebuah nama yang legendaris dan angker dalam lintasan sejarah perjuangan bangsa Indonesia. Mengenai keangkerannya, seorang pejabat Belanda menulis: "orang-orang yang berumur 27 tahun, sesudah 10 tahun diinternir, berubah dan patah semangat, dan badannya kelihatan tua. Yang sama sekali rusak adalah mereka yang usianya mendekati 50 tahun.” (Manangsang, 2007: 331; Mrazek, 1994: 141).

Keganjilan ini tidak hanya psikologis, tetapi sangat terlembaga. Kehidupan yang terstruktur di Tanah Merah terdiri atas empat kategori utama, yaitu de werkwillinger, de eigenwerkzoekenden, de steuntrekkers, de naturalisten (Shiraishi, 2001: 30-33).

\section{De Werkwillinger}

De Werkwillinger adalah mereka yang mau bekerja sama dengan pemerintah. Para interni yang masuk kategori ini bekerja pada beragam pekerjaan: sebagai kepala kampung dan juru tulis pada kantor pemerintah, perawat di rumah sakit, pekerja dinas pengendali malaria, juru tulis dan kuli di gudang pelabuhan, pekerja teknik di pusat tenaga listrik dan kantor telepon, polisi, guru, dan pekerja kasar di sawahsawah. Seluruh kategori pekerjaan ini digaji oleh pemerintah. Mereka yang mendapatkan gaji terendah adalah pekerja di sawah, gaji mereka $f$. 40 sen sehari, sekitar f. 10.50 sebulan untuk pekerjaan yang dimulai pukul 07.30 pagi hingga pukul 13.00 siang. Sementara itu, juru tulis dan pekerja teknik mendapatkan bayaran lebih baik, gaji bulanan mereka berkisar f. 18.75 hingga $f$. 30. Gaji tertinggi didapat juru tulis pada kantor pemerintah yang mendapatkan f. 90 sebulan.

Kategori ini merupakan mayoritas di Tanah Merah dan mereka sangat berharap dibebaskan dari Digoel. Semakin baik mereka bertingkah laku dan koopertif dengan pemerintah, mereka memiliki kesempatan besar untuk pulang. Menurut laporan Hillen 1930 jumlah mereka adalah 490 orang. Pasca kunjungan Hillen, mereka yang berjasa menormalkan kehidupan Tanah Merah, di antaranya Gondojuwono, Suprodjo, dan Suprapto dibebaskan di awal tahun 1931. Budisucitro yang memohon ampun kepada pemerintah ketika berada di Tanah Tinggi, 
dikembalikan ke Tanah Merah dan menggantikan Gondojuwono sebagai kepala kampung dan beberapa tahun kemudian dia dipulangkan.

\section{De Eigenwerkzoekenden}

De Eigenwerkzoekenden atau pekerja mandiri. Mereka yang paling kecil kemungkinan untuk dibebaskan dari Digoel. Para interni ini terdiri dari nelayan, petani sayur-mayur, pemilik toko kelontong dan warung, tukang pangkas rambut, pembuat roti, tukang jahit, pembuat sepatu, fotografer, guru kursus swasta. Mereka menerima jatah makan, $18 \mathrm{~kg}$ beras per bulan, hingga mereka mampu menghidupi diri sendiri. Menurut laporan Hillen tahun 1930 jumlah kategori ini adalah 350 orang.

\section{De Steuntrekkers}

De steuntrekkers adalah mereka yang invalid atau penerima bantuan. Para interni ini adalah orang dengan penyakit kronis seperti malaria dan $\mathrm{TBC}$, penderita gangguan jiwa atau mereka yang gila karena isolasi yang lama. Jumlah kategori ini sesuai laporan Hillen tahun 1930 adalah 40 orang.

\section{De Naturalisten}

De Naturalisten atau kaum naturalis, adalah mereka yang menolak bekerja untuk pemerintah. Akan tetapi, mereka tetap mendapat jatah makan gratis dari pemerintah dalam bentuk in natura \{barang\}. Pemerintah atau penguasa lokal memandang mereka sebagai kaum ekstremis yang tidak dikehendaki sehingga mereka selalu menjadi target utama yang selalu diawasi gerak-geriknya. Sesuai laporan Hillen pada 1930 jumlah kaum naturalis adalah 225 orang.

\section{Kamp Konsentrasi Tanah Tinggi}

Kamp Konsentrasi Tanah Tinggi khusus diperuntukkan bagi interni yang masuk kategori onverzoenlijken, yaitu mereka yang keras kepala, nekad, berkemauan baja, berprinsip, dan tidak mau menyerah. Mereka menahan harapan untuk pulang dan bertahan dalam kehidupan yang buruk. Kecuali jatah makanan rutin yang disediakan pemerintah, mereka mengurus seluruh kebutuhannya sendiri. Berdasar laporan Hillen 1930 jumlah penghuni di Tanah Tinggi 115 orang terdiri dari 70 interni dan 45 anggota keluarga.

Pada waktu Hillen berkunjung ke Tanah Tinggi, ia sempat berdialog dengan Nayoan, seorang bekas ketua Serikat Kereta Api, VSTP, dan anggota PKI sejak masa ISDV. Akhirnya Nayoan hilang di hutan pada 1942 dalam percobaan keempat dan terakhir untuk melarikan diri. Tidak dapat dibantah bahwa alam merupakan penguasa yang utama di Tanah Tinggi dan menjadi satu-satunya penentu.

Pada pertengahan 1930-an, para interni yang tinggal di Tanah Tinggi terbagi ke dalam tiga "klik". Pertama, kelompok yang terus melihat Aliarcham sebagai pemimpin mereka, sebuah teladan yang harus diikuti tentang seorang komunis yang seharusnya, jauh setelah kematiannya pada 1931. Kedua, kelompok yang dipimpin oleh Sarjono, Ngadiman, dan Winanta, yang membangun kader komunis mereka sendiri di dunia hutan rimba ini. Ketiga, kelompok yang dipimpin oleh tiga kader PKI yang kembali dari Moskow: Waworuntu, Daniel Kamu, dan Clementi Wantuk. Mereka sangat bangga dengan pelatihan yang didapatnya di Moskow dan bersikeras bahwa semua buku tentang komunis, selain yang diterbitkan di Rusia adalah palsu.

Pada 1935 tiga kelompok ini bertemu, dan setelah berdiskusi panjang, mereka menyepakati "Konvensi Anti Pen-Digoel-an", yang intinya bersepakat untuk tidak menyerah. Akan tetapi, Sarjono mengakhiri sikap kerasnya pada 1937, dan berargumentasi bahwa "tujuan membenarkan cara" sehingga ia dan kelompoknya meminta dipindahkan ke Tanah Merah. Selanjutnya kelompok Moskow mengikuti langkah ini tidak lama kemudian. Mereka pengkut Sejati Aliarcham hanya tinggal dengan jumlah seluruhnya 25 orang dan mampu bertahan hingga penutupan kamp pada 1943, waktu itu mereka dievakuasi ke Australia (Shiraishi, 2001: 39). 


\section{PENUTUPAN KAMP KONSENTRASI BOVEN DIGOEL}

Pada waktu Tjarda van Starkenborgh Statchouwer menggantikan de Jonge sebagai gubernur jenderal pada 1936, dan khususnya sejak Welter menjadi menteri urusan koloni pada 1937, Digoel yang untuk beberapa tahun terlupakan kembali menjadi isu besar di Den Haag dan Buitenzorg. Akan tetapi, yang lebih penting lagi karena situasi internasional berubah dengan cepat, ditambah Nazi berkuasa di Jerman dan invansi militer Jepang ke Cina dimulai. Selanjutnya, Welter mengirim nota kepada Petrus Blumberger untuk merancang surat kepada gubernur jenderal, untuk mendukung keputusannya membebaskan 20 interni dari Digoel sebagai langkah lebih lanjut menuju penutupan kamp konsentrasi kecuali bagi para onverzoenlijken.

Welter mengusulkan agar metode pembuangan di Digoel diganti lebih tradisional dalam waktu dekat. Caranya, para interni dibuang secara terpisah di banyak tempat sehingga mereka tidak lagi berharap dapat membangun pengaruh politik karena perbedaan bahasa dengan penduduk asli. Bahkan kamp konsentrasi di Digoel harus dihapuskan dengan perkecualian bagi mereka yang masuk kategori keras kepala.

Akan tetapi, keputusan untuk mempertahankan Digoel diambil pada pertemuan Dewan Hindia Belanda bulan Desember 1938. Selanjutnya, pada bulan Juli tahun 1938, 118 interni dibebaskan, sehingga mengurangi populasi interni di Digoel menjadi 345 termasuk 42 interni di Tanah Tinggi.

Akhirnya, Digoel ditutup tahun 1943, karena pemerintah Hindia Belanda di pengsingan di Melbourne (Australia) menjadi sangat ketakutan tentang kemungkinan para interni dibebaskan oleh Jepang. Oleh karena itu, pemerintah Hindia Belanda di pengasingan memutuskan untuk menghapuskan sama sekali dan mengungsikan semua interni ke Australia. Evakuasi dilakukan oleh Ch. O. Van der Plas dan kamp konsentrasi benar-benar ditutup tahun 1943.

\section{CITRA KAMP KONSENTRASI BOVEN DIGOEL ERA OTONOMI KHUSUS PAPUA}

\section{Citra Kamp Konsentrasi Boven Digoel}

Dalam perkembangannya Kamp Konsentrasi Boven Digoel dikenal sebagai tempat pembuangan komunis. Citra ini tidaklah benar sepenuhnya. Ada kekaburan batasan tentang siapa yang dikatakan sebagai komunis. Juga dalam masa penahanan massal tanpa prosedur pengadilan, amat besar kemungkinan terjadi kesalahan dalam penangkapan, ataupun penangkapan yang didasarkan pada motif-motif nonpolitis (misalnya balas dendam penguasa setempat). Pemerintah Hindia Belanda sendiri belakangan mengakui kemungkinan terjadinya kekeliruan-kekeliruan yang dilakukan aparatnya.

Dalam perkembangannya kemudian, Boven Digoel digunakan sebagai salah satu tempat pembuangan kekuatan anti kolonial dalam artian luas. Sejak 1932, banyak tokoh Partai Republik Indonesia (PARI), Partai Nasional Indonesia (PNI), Partai Indonesia (PARTINDO), Perhimpunan Muslim Indonesia (PERMI), Partai Sarikat Islam Indonesia (PSII), dan beberapa lainnya dibuang ke Boven Digoel. Hatta dan Sjahrir adalah dua contoh yang paling dikenal. Adik H. Agus Salim, I.F.M. Salim, wartawan yang terkenal cukup vokal juga ditempatkan/dibuang ke Boven Digoel.

Selain tokoh-tokoh partai politik tingkat nasional, pada perkembangan berikutnya khususnya setelah Indonesia merdeka, dan Tanah Papua masih berada di bawah kekuasaan kolonial Belanda, Kamp Konsentrasi Boven Digoel tetap difungsikan sebagai tempat buangan bagi elite-elite Papua yang menentang kekuasaan penjajah Belanda. Diantara mereka adalah para aktivis dan tokoh dari berbagai organisasi pergerakan pendukung Proklamasi 
Indonesia yang tumbuh dan berkembang di Tanah Papua antara 1946 hingga 1963.

Menurut Adurrachman Surjomihardjo bahwa dasar hukum dari pembuangan ke Digoel tanpa proses pengadilan itu adalah hak luar biasa yang dimiliki Gubernur Jenderal Hindia Belanda. Akan tetapi, didasari oleh pembukaan wilayah baru dengan alasan ekonomis (Prisma No. 7, 1988: 19). Jadi, jauh sebelum pemberontakan terjadi, pemerintah Hindia Belanda sudah melihat perlunya membuka daerah-daerah baru di luar Jawa yang dapat dijadikan sumber ekonomi. Oleh karena itu, Digoel berdasar penelitian geologi, diduga memiliki kekayaan alam yang dibutuhkan. Boven Digoel direncanakan untuk menjadi konsentrasi pemukiman yang dibutuhkan untuk proses pembangunan daerah baru tersebut.

Sejak awal sejarahnya, sebenarnya ada sikap mendua di kalangan Pemerintah Kerajaan Belanda dalam melihat Kamp Konsentrasi Boven Digoel. Di satu pihak cara itu diakui sebagai cara yang efektif. Akan tetapi, di pihak lain ada kesadaran akan unsur ketidakadilan dalam cara penanganan para tahanan politik seperti itu. Persoalan tersebut pada mulanya terangkat setelah adanya seri artikel tentang Digoel pada awal September 1928 di surat kabar Nieuwe Rotterdamsche Courant, yang ditulis oleh wartawan terkemuka media tersebut, Dr. M. van Blankenstein (Prisma No. 7, 1988: 19). Secara rinci wartawan itu menuliskan perjalanannya ke Boven Digoel dan mengisahkan pertemuannya dengan banyak tawanan yang menyampaikan kesan dan pandangannya mengenai ketidakadilan (karena mereka ditahan tidak berdasar keputusan pengadilan). Dalam seri tulisan itu memang tidak akan ditemukan rekaman langsung terhadap pemerintah Belanda. Namun ia telah membuka mata para pembaca Belanda akan adanya kamp konsentrasi.

Mengingat bahwa pada awal abad ke-20 telah dikenal adanya arah etis dalam politik kolonial, maka adanya kamp konsentrasi itu dapat dianggap sebagai satu kegagalan ethische politiek. Ini menimbulkan pertimbanganpertimbangan politik dalam parlemen Belanda dan Volksraad di Hindia Belanda.

Pertimbangan-pertimbangan itu menumbuhkan kesadaran tentang segi-segi yang adil maupun kesewenang-wenangan dalam pelaksanaan politik kolonial.

Lebih lanjut Abdurrachman Surjomihardjo mengatakan bahwa ada sejumlah hal yang menyebabkan Digoel dalam penulisan sejarah nasional agak terpencil (Prisma No. 7, 1988: 20-21). Pertama, para penulis sejarah Hindia Belanda sendiri, yang karya-karyanya kemudian dijadikan acuan, umumnya tidak menempatkan gerakan radikal 1926 sebagai bagian dari pergerakan nasional. Petrus Blumberger, penulis pertama sejarah pergerakan nasional, melihat pemberontakan 1926 itu sebagai bagian dari gerakan komunis internasional.

Para penulis bukan sejarawan, kurang dapat membedakan dengan tegas ruang dan waktu pemberontakan 1926/1927 itu dengan pemberontakan PKI 1948. Ia menjadi demikian, pertama-tama karena penggalian sumber-sumbernya secara tuntas belum dikerjakan. Kedua, lebih karena kadar politik yang muncul dari situasi konflik di masa awal Republik Indonesia, yang bobotnya makin bertambah sehubungan dengan pemberontakan G 30S/PKI, September 1965. Masih banyak orang yang terlibat dalam situasi konflik itu yang masih hidup dan berperan dalam masyarakat dewasa ini.

Dalam panggung sejarah nasional Indonesia pun keberadaan Kamp Konsentrasi Boven Digoel sedikit sekali dibicarakan. Oleh karena itu, banyak peserta didik (siswa) di tingkat pendidikan dasar dan menengah, maupun mahasiswa di tingkat pendidikan tinggi, banyak yang tidak tahu akan keberadaan Digoel. Padahal tahun-tahun pascarevolusi 1927 hingga 1942 bisa dipahami dalam konteks keberadaan Digoel. Menurut Takashi Shiraishi, bahwa untuk menormalkan kehidupan di Hindia Belanda pada tahun-tahun ini, maka pemerintah kolonial membutuhkan dunia hantu Digoel (Shiraishi, 2001: 43). Digoel dan kamp konsentrasi berfungsi untuk menjaga dan merefleksikan kondisi normal, bahwa Digoel 
secara definitif menjadi pemisah garis batas antara normal dan abnormal, kooperasi dan non-kooperasi (garis keras), karenanya memisahkan tatanan kolonial yang rasional dan penduduk yang berada di ambang kegilaan. Dan keseluruhan ini mencerminkan rezim yang melembagakan dan meminggirkan Digoel. Normalitas menjadi tergantung pada sebuah aparatus pengamanan yang kompleks yang menandai dan memecah kawasan, subjek, dan tanda-tanda kolonial.

Menciptakan tatanan dan rezim di Digoel sangatlah mudah, dengan cara diisolasi, dan tidak perlu ada catatan sejarah. Sejumlah kecil tawanannya masing-masing diidentifikasi secara lengkap: nama dan nama samarannya, nomor pengenal, tempat dan tanggal kelahiran, status pernikahan, pendidikan, latar belakang pekerjaan, karir politik, tanda tangan, fotografi, dan informasi lain yang berada dalam satu berkas. Semua berkas berada dalam satu ruangan. Sebaliknya, menciptakan tatanan rezim baru di Hindia Belanda jauh lebih rumit, karena rezim ini berada dalam kerajaan kepulauan yang luas, mempunyai jutaan penduduk (pada 1930), dengan sejarah, kebudayaan, dan bahasa yang berbeda-beda. Perangkat kenegaraannya berkembang membentang di berbagai daerah selama berabad-abad. Namun demikian, suatu tatanan rezim baru, yang benar-benar seragam dibentuk pada 1930-an dengan penjara dan kamp-kamp tawanan, kekuatan polisi modern yang relatif kecil (34.000 kekuatan pada 1930), dan sejumlah kecil angkatan bersenjata kolonial (37.000 kekuatan pada 1930) (Indisch Verslag 1931: 14, 405-406).

\section{KAMP KONSENTRASI BOVEN DIGOEL ERA OTONOMI KHUSUS PAPUA}

Kamp pengasingan Boven Digoel seluas 27,8 kilometer persegi, yang mana lahan seluas 1.000 meter persegi untuk kamp militer, kompleks pemerintahan, penjara, dan barak-barak hunian (Kompas, 30 Mei 2012). Penghuni awal kamp ini tahanan politik yang terlibat pemberontakan
PKI 1926 di Jawa Barat dan 1927 di Sumatera Barat. Meski awalnya identik dengan pembuangan kaum komunis, Belanda akhirnya juga menjadikan tempat ini sebagai pembuangan tokoh nasionalis, khususnya mereka yang menganut prinsip nonkooperatif seperti Bung Hatta dan Sutan Syahrir.

Saat ini kondisi eks Kamp Konsentrasi Boven Digoel telah mengalami banyak sekali perubahan dari kondisi asli. Eks Kamp Konsentrasi Boven Digoel berada di sekitar pemukiman penduduk dan sebagian area menjadi kantor Polres Kabupaten Boven Digoel. Oleh karena itu, kondisi fisik bangunan tentunya mengalami beberapa renovasi untuk disesuaikan dengan kebutuhan saat ini. Hal ini tentunya akan mengurangi nilai historis bangunan Eks Kamp Konsentrasi Boven Digoel.

Pada 2012, Dinas Kebudayaan dan Pariwisata Kabupaten Boven Digoel memiliki program kunjungan ke Belanda untuk memperkenalkan situs sejarah tempat pengasingan para tokoh pejuang/perintis kemerdekaan Indonesia (Kompas, 29 Mei 2012). Usaha memperkenalkan situs sejarah tersebut kepada publik luar negeri (Belanda) perlu mendapat apresiasi, tetapi yang tidak kalah penting adalah kepedulian pemda untuk merawat, menjaga, dan melestarikan situs dari kerusakan adalah langkah yang tidak bisa ditawar lagi. Bilamana kompleks situs tertata dan terawat dengan baik dapat dijadikan sebagai media pembelajaran siswa dari PAUD/TK hingga perguruan tinggi dan untuk dikembangkan sebagai destinasi wisata sejarah yang dapat mengangkat pamor Boven Digoel baik lingkup lokal, nasional, dan global (Handoko, dkk., 2008: 51).

Menurut hemat penulis, pemerintah pusat melalui kementerian terkait sudah selayaknya turun tangan atau lebih intens lagi menangani situs sejarah eks Kamp Konsentrasi Boven Digoel. Oleh karena keberadaan eks Kamp Konsentrasi Boven Digoel pada masa silam (kolonial) gaungnya tersebar ke penjuru Nusantara dan Eropa. Apalagi saat ini (sejak 
tahun 2012) Monumen Bung Hatta sudah berdiri kokoh di depan situs sejarah tersebut yang menandakan eksistensinya sejak masa pergerakan nasional.

\section{SIMPULAN}

Penunjukan Boven Digoel sebagai tempat pengasingan kaum pergerakan karena beberapa faktor baik secara langsung maupun tidak langsung, antara lain: Pertama, makin intensifnya gerakan radikal (komunis) di Indonesia periode 1925-1927 yang termanifestasi dalam berbagai pemogokan buruh dan pemberontakan. Aktivitas ini merupakan ancaman yang harus dihentikan oleh pemerintah kolonial untuk menjaga rust en order. Kedua, Negeri Belanda merupakan kekuatan kolonial yang minor atau kecil, bilamana dibandingkan dengan Spanyol, Portugis, Perancis, dan Inggris. Artinya, hanya wilayah Hindia Belanda (Indonesia) yang memiliki arti strategis bagi keberlangsungan kolonialisme. Oleh karena itu, lebih strategis jika mendirikan tempat pengasingan bagi kaum pergerakan tetap di wilayah Hindia Belanda daripada di luar negeri (Belanda). Dipilihlah tempat (Boven Digoel) yang jaraknya sangat jauh dari pusat pemerintahan di Batavia. Ketiga, Daerah Boven Digoel letaknya di hulu Sungai Digoel, Papua bagian Selatan. Wilayah ini pada awalnya (saat itu) diselimuti oleh hutan belukar lebat, penuh dengan rawa-rawa dan sunyi-senyap dengan beraneka ragam binatang buas, ganasnya nyamuk malaria, dan suku asli yang masih kanibal. Oleh karena itu, Pemerintah Kolonial Belanda merasa cocok untuk mendirikan kamp konsentrasi atau tempat pembuangan/ pengasingan bagi para tahanan politik di wilayah ini. Kaum pergerakan yang dibuang ke Boven Digoel sangat susah untuk melarikan diri dari wilayah ini. Keempat, Boven Digoel direncakan kelak di kemudian hari sebagai 'Tanah Harapan' atau masa depan bagi kaum pergerakan. Artinya, kaum pergerakan tidak kembali ke daerah asalnya tetapi tetap di Boven Digoel menghabisnya hari tuanya. Hal ini dimaksudkan oleh pemerintah kolonial agar kaum pergerakan 'terputus' sama sekali dengan rakyatnya, sehingga mereka tidak bisa menyebarkan gagasan dan ide-ide kebangsaan atau nasionalisme.

Boven Digoel memiliki hubungan yang erat atau berperan penting dalam lintasan Sejarah Indonesia, khususnya masa pergerakan nasional. Kini di Era Reformasi Indonesia dan Otonomi Khusus Papua, eksistensi situs-situs sejarah di wilayah Boven Digoel selayaknya mendapat apresiasi dari para pemangku kepentingan baik di Tanah Papua maupun di tingkat pusat. Situs sejarah Boven Digoel harus segera dikelola dengan baik untuk kepentingan pembangunan pendidikan dan pariwisata. Keberadaan situs sejarah Boven Digoel dapat dimanfaatkan para guru IPS (sejarah) sebagai materi muatan lokal sejarah. Akan tetapi, hal ini belum sepenuhnya dimanfaatkan para guru di Papua. Pada masa yang akan datang situs sejarah Boven Digoel ke depan harus dikembangkan sebagai tempat wisata sejarah baik bagi para siswa/mahasiswa maupun para wisatawan baik lokal, nasional, maupun asing. Bilamana aspek pariwisata dikelola dengan baik maka akan berdampak pada perkembangan dunia pariwisata di Boven Digoel makin popular yang menjadi salah satu destinasi para wisatawan. Pada gilirannya perekonomian rakyat dapat diberdayakan mulai dari kerajinan tangan, kesenian (budaya), rumah makan, penginapan (hotel), dan lainnya .

\section{REFERENSI}

Garraghan, Gilbert J. (1957). A Guide to Historical Method. East Fordham Road \& New York: Fordham UP.

Gottschalk, Louis (1986). Mengerti Sejarah. (Terjemahan Nugroho Notosusanto), Jakarta: UI Press.

Handoko, Susanto T, dkk., (2008). Boven Digoel Dalam Sejarah Indonesia: Inventarisasi dan Dokumentasi Eks Penjaran Boven Digoel. Jayapura: Dinas Kebudayaan Provinsi Papua. 
Kartodirdjo, Sartono (1992). Pendekatan Ilmu Sosial dalam Metodologi Sejarah. Jakarta: Gramedia.

Kuntowijoyo (2003). Metodologi Sejarah, Yogyakarta: Tiara Wacana.

Manangsang, John (2007). Papua Sebuah Fakta dan Tragedi Anak Bangsa. Pergumulan: Etika, Moral, Hukum, Sosial, Budaya, Kedokteran, SDM dan Kemanusiaan. Jakarta: Yayasan Obor Indonesia.

Mangunadikusumo, Sunaryo, dkk. (1977). Citra Dan Perjuangan Perintis Kemerdekaan Seri Perjuangan Ex Digul. Jakarta: Depsos.

Mrazek, Rudolf (1994). Sjahrir: Politics and Exile in Indonesia. Cornell Southeast Asia Program.

------- (1996). Sjahrir: Politik dan Pengasingan di Indonesia. Jakarta: Yayasan Obor Indonesia.

Renier, G.J. (1997). Metode dan Manfaat Ilmu Sejarah. Yogyakarta: Pustaka Pelajar.

Salim, I.F.M. Chalid (1977). Lima Belas Tahun Digul: Kamp Konsentrasi di Nieuw Guinea Tempat Persemaian Kemerdekaan Indonesia. Jakarta: Bulan Bintang.

Suhartono (2010). Teori \& Metodologi Sejarah. Yogyakarta: Graha Ilmu.

Shiraishi, Takashi (2001). Hantu Digoel: Politik Pengamanan Politik Zaman Kolonial. Yogjakarta: LKiS.

Wasino (2016). Nasionalisasi PerusahaanPerusahaan Asing Menuju Ekonomi Berdikari. Jurnal Paramita. Vol. 26, No.1, Tahun 2016.

Yuniarti, Fandri dan Chris Verdiansyah (ed.) (2007). Laporan Jurnalistik Kompas: Ekspedisi Tanah Papua. Jakarta: Buku Kompas.

Kompas, 29 Mei 2012, “Jejak Nasionalisme Boven Digoel (5)”.

Kompas, 30 Mei 2012, "Jejak Nasionalisme Boven Digoel (6)”.

Prisma, No. 7, 1988.

Suara Perempuan Papua, 7-12 Agustus 2006. 